ISSN 0258-7122

Bangladesh J. Agril. Res. 33(3) : 539-548, December 2008

\title{
IMPACTS OF SULPHUR LEVELS ON YIELD, STORABILITY AND ECONOMIC RETURN OF ONION
}

\author{
M.H. ULLAH ${ }^{1}$, S.M.I. HUQ ${ }^{2}$, M.D.U. ALAM ${ }^{3}$ AND M.A. RAHMAN ${ }^{4}$
}

\begin{abstract}
The experiments were carried out at the Regional Agricultural Research Station, Rahmatpur, Barisal during the rabi seasons of 2001-2002 and 2002-2003 to study the impact of different sulphur levels on bulb yield, storability and economic return of onion. Sulphur application had significant effect on yield components and bulb yield of onion. The highest bulb yields (19.75 and 19.88 t/ha) were obtained from sulphur levels between 60 and $75 \mathrm{~kg} / \mathrm{ha}$ in two consecutive years. Both the cumulative weight and rotten loss were significantly influenced by sulphur fertilization. The maximum weight loss $(40.78 \%)$ was recorded after 180 days of storage in $\mathrm{S}_{60} \mathrm{~kg} / \mathrm{ha}$ and the minimum (31.40\%) was found in S45 kg/ha. The bulbs stored in bamboo platform were found in acceptable condition after 6 months of storage showing $31.40 \%$ of weight loss. The maximum rotten bulbs (63.75\%) were observed in control treatment (without S) and the minimum rotten bulbs (37.04\%) were observed in S45 kg/ha after 180 days of storage because application of sulphur enhanced the storability of onion bulbs. The highest (9146\%) marginal rate of return (MRR) with gross margin of Tk. 181844/ha was obtained from the sulphur level $\mathrm{S}_{60} \mathrm{~kg} / \mathrm{ha}$.
\end{abstract}

Key Words: Sulphur, yield, storability, economic return, onion.

\section{Introduction}

Among the spice crops grown in Bangladesh onion ranks second in acreage and first in production. Onion production of our country does not meet up the domestic demand. The total onion production is about 589.41 thousand metric tons in an area of 86.43 thousand hectares of land (BBS, 2007). where the national demand is about 687.65 thousand metric tons (FAO, 2005). The national average yield, of onion per hectare is only 6.91 tons, but the world average yield is about $17 \mathrm{t} / \mathrm{ha}$ (FAO, 1999). There is an acute shortage of onion in relation to its requirement. Due to limitation of land, it is not possible to raise the area and production of the crop horizontally. The high demand of onion can only be meet up by increasing its per hectare yield. This can be done by many ways of which the most important are the judicious application of fertilizers, introduction of high yielding varieties and proper management practices. In addition to NPK nutrients, sulphur has been found to be very beneficial for onion. It is essential for proper vegetative growth and bulb development. Inadequate supply of

\footnotetext{
${ }^{1}$ Principal Scientific Officer (Soil Science), ARS, Burirhat Farm, BARI, Rangpur ${ }^{2 \& 3}$ Professor, Dept. of Soil Water and Environment, Dhaka University, Dhaka and ${ }^{4}$ Senior Scientific Officer (Agronomy), OFRD, Barind Station, BARI, Rajshahi, Bangladesh.
} 
sulphur nutrient causes slow crop growth at any stage resulting in yield reduction. Moreover, most of the Bangladesh soils are deficient in available sulphur that roughly covers $44 \%$ of the total cropped area (Hussain, 1990).

Sulphur has been found not only to increase the bulb yield of onion but also improves its quality, especially pungency and flavour (Jaggi and Dixit, 1999). Severe sulphur deficiency during bulb development has detrimental effect on yield and quality of onion (Ajay and Singh, 1994). Sulphur containing secondary compounds are not only important for nutritive value or flavours but also for resistance against pest and diseases (Bell, 1981. Onion storage is important to provide product for fresh market, export and processing. Storage potential of onions mainly depends on the cultivar, climate conditions during growing season and storage methods (Adamicki, 2005). Storage of onion bulbs in the country is a serious problem for both growers and consumers. Rahim el al. (1983) reported that in some exotic cultivars, storage loss is even $100 \%$. The neck thickness and storability decreased with increasing levels of sulphur (Kumar el al., 2002). Therefore, the present study was undertaken to find out the optimum sulphur dose for increasing bulb yield and storability of onion.

\section{Materials and Method}

The experiment was carried out at the Regional Agricultural Research Station. Rahmatpur, Barisal during the rabi seasons of 2001-2002 to 2002-2003. The site belongings to the non-Calcareous Grey Floodplain soils of Ganges Tidal Flood plain Alluvium Tract under AEZ 13. Composite soil samples $(0-15 \mathrm{~cm}$ depth) were collected from the selected fields for determining the initial nutrient status of the soil. The analytical results of the soil samples from the experimental plots are presented below:

\begin{tabular}{l|l|l|l|l}
\hline Soil properties & $2001-2002$ & $2002-2003$ & Average & Critical values \\
\hline $\mathrm{P}^{\mathrm{H}}$ & 6.10 & 6.00 & 6.17 & - \\
Organic matter (\%) & 1.20 & 1.01 & 1.06 & \\
Active acidity (\%) & 0.18 & 0.21 & .20 & \\
$\mathrm{Ca}(\mathrm{meq} / 100 \mathrm{ml})$ & 1.44 & 1.17 & 1.37 & 2.00 \\
$\mathrm{Mg}(\mathrm{meq} / 100 \mathrm{ml})$ & 3.55 & 4.01 & 3.50 & 0.80 \\
$\mathrm{~K}(\mathrm{meq} / 100 \mathrm{ml})$ & 4.75 & 4.59 & 4.42 & 0.20 \\
$\mathrm{NH} 4-\mathrm{N}(\mathrm{ppm})$ & 13.00 & 11.00 & 14.00 & 75.00 \\
Available P(ppm) & 13.00 & 14.00 & 12.67 & 14.00 \\
Available S (ppm) & 11.00 & 13.00 & 12.00 & 14.00 \\
Available Zn (ppm) & 3.00 & 4.00 & 3.00 & 2.00 \\
\hline
\end{tabular}

The experiment was laid out in randomized complete block design (RCBD) with four replications. The treatments consisted of eight levels of sulphur $(0,15$, 30, 45, 60, 75. 90 and $105 \mathrm{~kg} / \mathrm{ha}$ ). The unit plot size was $3 \mathrm{~m} \mathrm{x} 4 \mathrm{~m}$. A blanket dose of $\mathrm{N}_{100} \mathrm{P}_{80} \mathrm{~K}_{100} \mathrm{~kg} / \mathrm{ha}$ with cowdung $5 \mathrm{t} / \mathrm{ha}$ were used with each treatment. 
Among the blanket dose of NPK fertilizers $1 / 3 \mathrm{~N}$ and whole amount of PK were applied at the time of final land preparation in the form of urea, triple super phosphate and muriate of potash, respectively. Well decomposed cowdung @ $5 \mathrm{t}$ /ha was also used at the same time. The remaining $2 / 3^{\text {rd }}$ urea was apnlied in two equal installments during $3^{\text {rd }}$ and the $5^{\text {th }}$ week after transplanting as top dressing. Onion seedlings of 45 days old were transplanted on the 28 December 2001 and 30 December 2002. BARI Peaj 1 was used for the present study. The row-to-row and plant-to-plant spacing were $20 \mathrm{~cm}$ and $10 \mathrm{~cm}$, respectively. After transplanting the seedlings, various kinds of intercultural operations were accomplished for better growth and development of the plants. Weeding and mulching were done when necessary to keep the crop free from weeds and to pulverize the soil. The young plants were irrigated by water cane. Threeirrigations were given during the cropping period. Preventive measure was taken against soil borne insect. For the prevention of cutworm (Agrotis ypsilon) soil treatment was done with Furadan 3 G @ 20 kg/ha. No incidence of insect pest infestation was found in the field but after few days during growth period some of the plants were attacked by purple blotch disease caused by Alternaria porn. It was controlled by spraying the crop with Rovral $50 \mathrm{WP}$ in due time. Bolting was discouraged by nipping off the flower stalks whenever they appeared during the growing period of the crop and the flowering stalk or bolting was broken and removed whenever appeared in the plants. The crop was harvested on 4 April 2002 and 7 April 2003 when $80 \%$ of the plants showed the sign of maturity by drying out most of the leaves and they collapsed at the neck of the tops. The yield attributes of onion were recorded from the randomly selected ten plants collected from each unit plots during harvest. The bulb yield was taken plot-wise and thereafter converted into ton per hectare. The storability was observed after harvest of onion bulb at different days after storage. The data were analysed statistically and the means were separated by Duncan's Multiple Range Test (Gomez and Gomez. 1984).

\section{Results and Discussion}

\section{Effect of sulphur levels on yield and yield components of onion}

Yield and yield attributes of onion bulbs as influenced by sulphur fertilization are presented in Table 1. Sulphur fertilizer had significant positive influence on the weight of single bulb, diameter of bulb and bulb yield upto certain level. Weight of single bulb ranged from 21.0 to 40.0 g 2001-2002, 22.25 to 35.75 g 2002-2003 across the sulphur levels. Weight of single bulb was the highest in plants treated with $75 \mathrm{~kg}$ S/ha. Plant receiving 45 or $60 \mathrm{~kg}$ S/ha had significant effect on single bulb weight. Further increase in sulphur fertilizer tended to decrease the single weight of bulb irrespective of years. Application of $S_{0} \mathrm{~kg} /$ ha gave the lowest bulb weight. The results are in agreement with that of Ahmed et al. (1988). 
Bulb diameter varied significantly due to sulphur fertilization. Bulb diameter ranged from 3.66 to $4.51 \mathrm{~cm}$ in 2001-2002 and $4.5 \mathrm{~cm}$ to $5.18 \mathrm{~cm}$ in 2002- 2003 across the sulphur levels. Plants treated with $75 \mathrm{~kg} \mathrm{~S} / \mathrm{ha}$ showed that the largest bulb diameter. Beyond $75 \mathrm{~kg}$ S/ha, decreasing tendency of bulb diameter was observed. Further increase in sulphur rate produced no advantage in diameter weight.

The bulb yield ( $\mathrm{t} / \mathrm{ha}$ ) of onion was also varied significantly due to sulphur application in all the years (Table 5). Bulb yield differed from 10.46 to $19.75 \mathrm{t} / \mathrm{ha}$ in 2001-2002 and 10.58 to $19.88 \mathrm{t} / \mathrm{ha}$ in 2002-2003. The maximum bulb yield was observed with $75 \mathrm{~kg}$ S/ha followed by $60 \mathrm{~kg} \mathrm{~S} / \mathrm{ha}$ in both the years. Application of sulphur at $75 \mathrm{~kg} /$ ha gave the yield advantage of $88.81 \%$ and 87.90\% higher over the control in 2001-2002 and 2002-2003, respectively. It can be conclusively inferred that onion yield can be increased with sulphur fertilizer upto $75 \mathrm{~kg} / \mathrm{ha}$ and expected yield is around $20 \mathrm{t} / \mathrm{ha}$. Similar results were also reported by Singh el al. (1996). There was a significant increase in bulb yield due to fertilizer application suggesting that the soil was highly deficient in sulphur that resulted a larger yield difference. Moreover, increase in bulb yield under 60 or $75 \mathrm{~kg} \mathrm{~S} / \mathrm{ha}$ might be due to production of taller plants with higher number of leaves leading to increase formation of vegetative structure for nutrient absorption and photosynthesis and increased production of assimilates to fill the sink, resulting in increased bulb size and weight. However, beyond $75 \mathrm{~kg} \mathrm{~S} / \mathrm{ha}$ negative response of sulphur application was recorded. Plants grown without sulphur had the lowest bulb yield. Sulphur deficiency had an adverse effect in terms of poor growth and low yield of onion.

Table 1. Yield components and yield of onion bulb as influenced by sulphur fertilization.

\begin{tabular}{l|lllll|ll}
\hline $\begin{array}{c}\text { Sulphur } \\
\text { levels } \\
(\mathrm{kg} / \mathrm{ha})\end{array}$ & Wt of single bulb (g) & \multicolumn{2}{l|}{ Diameter of bulb (cm) } & Yield of bulb (t!ha) \\
\hline 0 & $2001-2002$ & $2002-2003$ & $2001-2002$ & $2002-2003$ & $2001-2002$ & $2002-2003$ \\
0 & $21.00 \mathrm{c}$ & $22.25 \mathrm{c}$ & $3.66 \mathrm{~d}$ & $4.50 \mathrm{c}$ & $10.46 \mathrm{~d}$ & $10.58 \mathrm{~d}$ \\
15 & $23.00 \mathrm{~d}$ & $27.00 \mathrm{~d}$ & $3.96 \mathrm{c}$ & $4.54 \mathrm{c}$ & $12.15 \mathrm{~cd}$ & $11.50 \mathrm{~d}$ \\
30 & $26.00 \mathrm{c}$ & $29.53 \mathrm{~cd}$ & $4.1 \mathrm{lc}$ & $4.70 \mathrm{abc}$ & $13.2 \mathrm{Obc}$ & $13.20 \mathrm{c}$ \\
45 & $31.00 \mathrm{~b}$ & $31.50 \mathrm{bc}$ & $4.2 \mathrm{bbc}$ & $4.91 \mathrm{abc}$ & $15.25 \mathrm{~b}$ & $15.25 \mathrm{~b}$ \\
60 & $40.00 \mathrm{a}$ & $32.75 \mathrm{abc}$ & $4.48 \mathrm{a}$ & $5.10 \mathrm{ab}$ & $18.33 \mathrm{a}$ & $19.75 \mathrm{a}$ \\
75 & $40.00 \mathrm{a}$ & $35.75 \mathrm{a}$ & $4.51 \mathrm{a}$ & $5.18 \mathrm{a}$ & $19.75 \mathrm{a}$ & $19.88 \mathrm{a}$ \\
90 & $40.00 \mathrm{a}$ & $33.90 \mathrm{ab}$ & $4.37 \mathrm{ab}$ & $4.39 \mathrm{abc}$ & $19.70 \mathrm{a}$ & $19.13 \mathrm{a}$ \\
105 & $39.00 \mathrm{a}$ & $34.00 \mathrm{ab}$ & $4.36 \mathrm{ab}$ & $4.60 \mathrm{bc}$ & $19.00 \mathrm{a}$ & $19.08 \mathrm{a}$ \\
\hline CV (\%) & 4.1 & 4.0 & 3.8 & 6.9 & 7.6 & 4.4 \\
F-test & $* *$ & $* *$ & $* *$ & $* *$ & $* *$ & $* *$ \\
\hline
\end{tabular}




\section{Relationship between sulphur levels and bulb yield of onion during}

Averaged over years, yield response to applied sulphur followed a quadratic (Ya+bx cx) relationship (Fig. I). The value of $\mathrm{R}_{2}$ indicates that the sulphur levels can attribute to $95 \%$ for $2001-2002$ and $91 \%$ for 2002-2003 of the total variation in bulb yield. It means that over $90 \%$ of variation in minimum yield could be attributed to $\mathrm{S}$ nutrition.
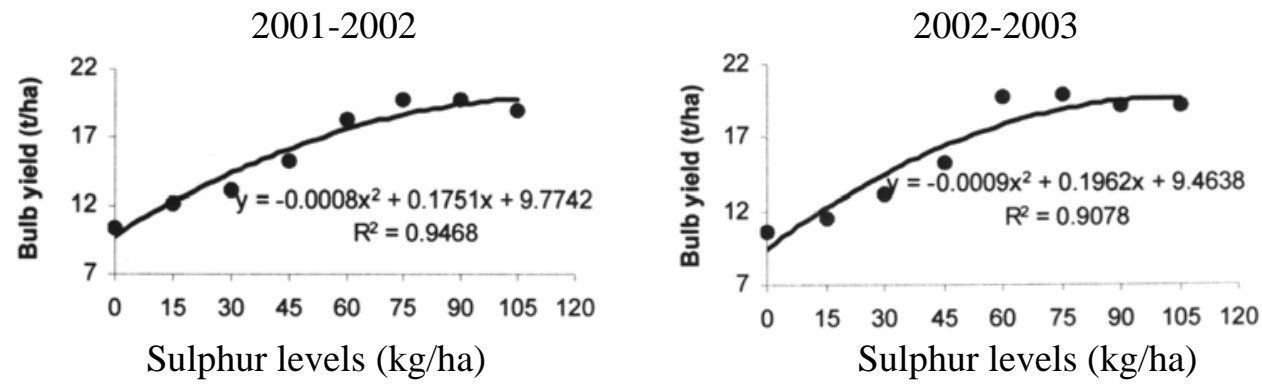

Fig. 1. Relationship between sulphur lwvels and bulb yield of onion.

Relationship between rotting and weight loss of onion bulb during storage as influenced by sulphur levels

When data on weight loss of onion stored on bamboo platform was regressed against the number of rotting of onion bulbs, a linear relationship observed between them. It was obvious that the equation $Y=0.0046 \times 2+1.046 x-1.6828$ gave a good fit to the data and the co-efficient $R^{2}=0.9687$ value showed that the fitted regression line had a significant regression coefficient. This indIcated that the weight loss increased with increasing percentage of rotting of onion bulbs during storage (Fig. 2).

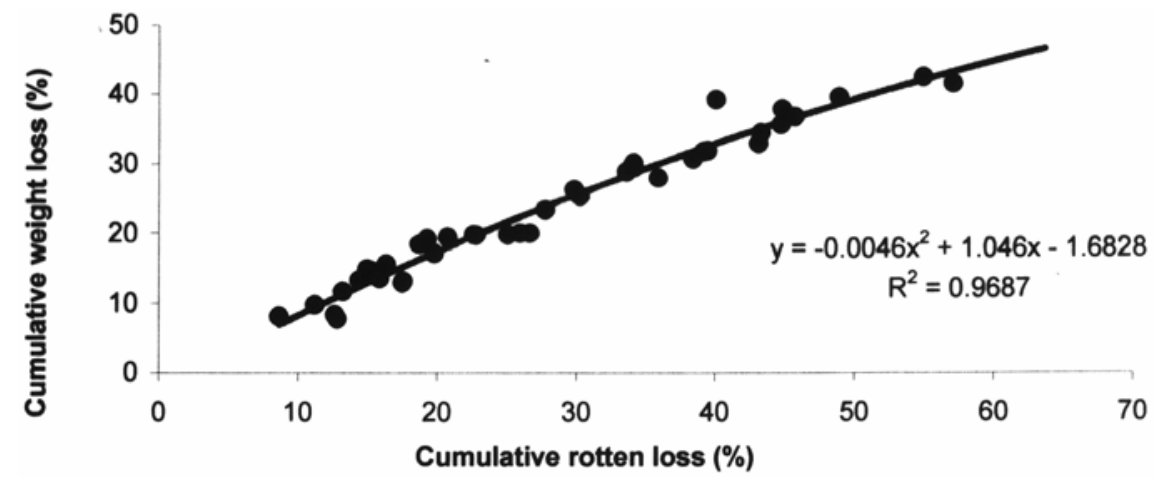

Fig. 2. Correlation between rottening and weight loss of onion bulb during storage (average two years). 
Relationship between sprouting and weight loss as influenced by sulphur levels

A positive linear relationship was observed between weight loss of onion and number of sprouted onions during storage when data was regressed (Fig. 3). Here, the equation was Y6.4933x2-I42.O2x+8 13.26 and the value of the coefficient of determination $\mathrm{R}^{2}=0.3204$ gave best fit and showed that the fitted regression line had a significant regression coefficient. This indicated that the weight loss of onion was in creased when the number of sprouted onion increased during the storage.

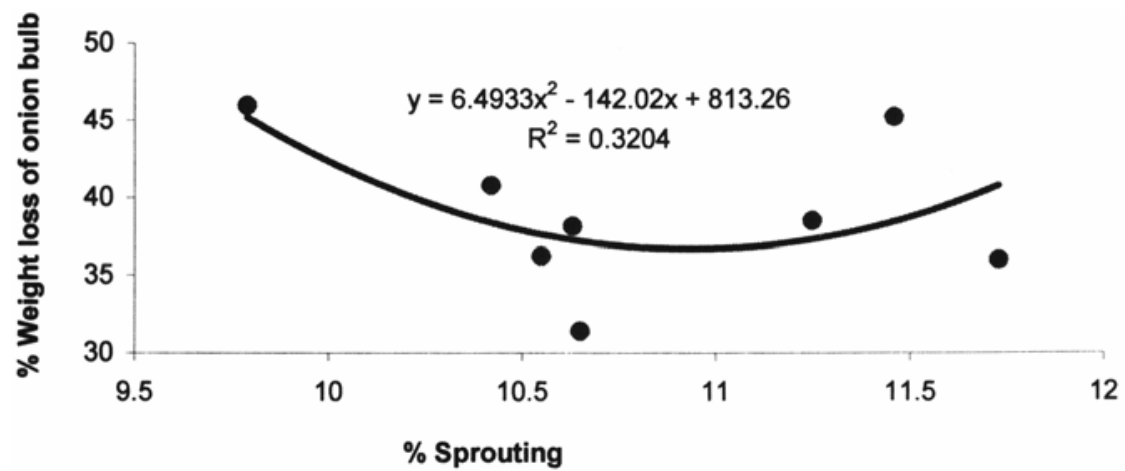

Fig. 3. Relationship between sprouting and weight loss of onion bulb (average 2 years).

\section{Cumulative weight loss of onion bulb during storage}

The percentage of weight loss of onion bulbs at different periods of storage was significantly influenced by sulphur fertilization (Table 2). In periodical observation at an interval of 30 days, it was found that the stored bulbs of all treatments lost weight gradually and the maximum weight loss $(40.78 \%)$ was recorded after 180 days of storage in $60 \mathrm{~kg} \mathrm{~S} / \mathrm{ha}$ and the minimum (31.40\%) was found in $45 \mathrm{~kg} \mathrm{~S} / \mathrm{ha}$. At lower sulphur supply, the sulphur percentage in cell walls was reduced. Bulbs grown at low sulphur supply had reduced firmness and pungency. Therefore, storage may be adversely affected at low sulphur supply (Lancaster, 2001). The bulbs stored on bamboo platform were found in acceptable condition after 6 month of storage showing 31.40\% of weight loss. The present findings are in agreement with the results observed by researchers of BAR! (Anonymous, 1999) who also reported minimum weight loss in onion bulb stored in bamboo rack.

Loss in weight of bulb is usually known to be occurred due to rotting, dehydration transpiration, respiration, sprouting, etc. The weight loss is generally caused due to prevailing high temperature, high humidity in storage environment. This is closely related to the moisture deficiency of the surrounding air rather than temperature. It is observed that although high humidity effectively reduced 
weight loss, however, favoured fungal development, especially at high temperature. When growing onions from sets, the yield does not depend on the age of the sets, but only on their weight and the storage temperature (Palilov, 2005).

Table 2. Percentage of cumulative weight loss of onion bulb during storage as influenced by suipher fertilization (average of two years).

\begin{tabular}{l|llllll}
\hline $\begin{array}{c}\text { Sulphur } \\
\text { levels } \\
\text { (kg/ha) }\end{array}$ & \multicolumn{7}{c}{ Bulb weight loss (\%) at different days after storing } \\
\hline & 30 & 60 & 90 & 120 & 150 & 180 \\
$5_{0}$ & $15.63 a$ & $19.82 \mathrm{a}$ & $28.85 \mathrm{a}$ & $39.49 \mathrm{a}$ & $41.42 \mathrm{a}$ & $45.96 \mathrm{a}$ \\
$\mathrm{S}_{15}$ & $13.60 \mathrm{~b}$ & $19.76 \mathrm{a}$ & $25.33 \mathrm{~b}$ & $36.65 \mathrm{a}$ & $42.36 \mathrm{a}$ & $45.23 \mathrm{a}$ \\
$\mathrm{S}_{30}$ & $11.73 \mathrm{c}$ & $17.15 \mathrm{ab}$ & $23.33 \mathrm{~b}$ & $31.73 \mathrm{~b}$ & $35.57 \mathrm{bc}$ & $38.52 \mathrm{bc}$ \\
$\mathrm{S}_{45}$ & $8.22 \mathrm{e}$ & $13.40 \mathrm{c}$ & $19.26 \mathrm{c}$ & $26.33 \mathrm{~d}$ & $\mathrm{~L} 29.46 \mathrm{~d}$ & $31.40 \mathrm{~d}$ \\
$\mathrm{~S}_{60}$ & $14.97 \mathrm{a}$ & $18.48 \mathrm{a}$ & $20.02 \mathrm{c}$ & $31.81 \mathrm{~b}$ & $37.78 \mathrm{~b}$ & $40.78 \mathrm{~b}$ \\
$\mathrm{~S}_{75}$ & $9.87 \mathrm{~d}$ & $14.75 \mathrm{bc}$ & $19.44 \mathrm{c}$ & $30.09 \mathrm{bc}$ & $39.12 \mathrm{c}$ & $36.23 \mathrm{c}$ \\
$\mathrm{S}_{90}$ & $8.46 \mathrm{e}$ & $12.98 \mathrm{c}$ & $20.03 \mathrm{c}$ & $27.97 \mathrm{~cd}$ & $32.82 \mathrm{c}$ & $36.0 I \mathrm{c}$ \\
$\mathrm{S}_{105}$ & $7.88 \mathrm{e}$ & $13.22 \mathrm{c}$ & $19.81 \mathrm{c}$ & $30.67 \mathrm{bc}$ & $34.37 \mathrm{c}$ & $38.15 \mathrm{c}$ \\
\hline $\mathrm{CV}(\%)$ & 6.3 & 13.0 & 6.4 & 6.6 & 5.8 & 4.7 \\
\hline
\end{tabular}

\section{Cumulative rotten loss of onion bulb during storage}

Percentage of rotten bulbs of onion at different days after storage was significantly influenced by sulphur fertilization (Table 3 ). The highest percentage of rotten bulbs (63.75\%) after 180 days of storage was observed in the control treatments (without sulphur). The minimum value of $37.04 \%$ (loss) being noted for crops grown with $45 \mathrm{~kg} \mathrm{~S} / \mathrm{ha}$. It reveals from the findings that sulphur addition has favoured storability of onion bulbs. Lancaster et al. (2001) reported that bulbs grown at low sulphur supply reduced firmness and pungency. Therefore, storage may be adversely affected at low sulphur supply. Rafika et al. (2005) reported that storage life was correlated with dry matter content.

During storage, two diseases, namely bacterial soft rot (Erwinia caratovora) and black mold (Aspergillus niger) were observed in onions of all the treatments. These diseases attacked different parts from base to the neck of the bulbs. The tissues of the onions were affected by soft rot like water soaked and appeared shrunken and brownish in the advance stages of infection. Black mold rot produced black powdery masses on the outside scale, following the veins. Similar results were found by Srinivasan et al. (2002) reported that Aspergillus niger was found to be the predominant pathogen associated with black mould rot of onion during storage. Application of higher doses of calcium in the form of gypsum (400 kg/ha) and lower dose of nitrogen in the form of urea $(50 \mathrm{~kg} / \mathrm{ha})$ to the field and advancing the harvest of onion bulbs by fifteen days significantly reduced the spoilage of bulbs during storage. Ahmed and Rashid (1981) opined 
that the rotting in stored onion was caused by both bacterial and fungi and among the fungi Aspergillus, Botrytis and Colletotrichum, were identified. Onion kept in bamboo rack remained drier compared to other methods, which was perhaps the reasons of less rotting.

Table 3. Percentage of cumulative rotten loss of onion bulb at various days during storage as influenced by Sulphur fertilization (average of two years).

\begin{tabular}{|c|c|c|c|c|c|c|}
\hline \multirow{2}{*}{$\begin{array}{c}\begin{array}{c}\text { Sulphur } \\
\text { levels } \\
(\mathrm{kg} / \mathrm{ha})\end{array} \\
\end{array}$} & \multicolumn{6}{|c|}{ Rotten loss (\%) at different days after storing } \\
\hline & 30 & 60 & 90 & 120 & 150 & 180 \\
\hline $5_{0}$ & 16.36a & $22.64 a$ & 33.63a & 48.94a & 57.13a & 63.73a \\
\hline $\mathrm{S}_{15}$ & 15.89ab & $22.82 \mathrm{a}$ & $30.28 b$ & $45.78 \mathrm{~b}$ & $54.96 \mathrm{a}$ & 60.38a \\
\hline $\mathrm{S}_{30}$ & $13.23 \mathrm{c}$ & $19.80 \mathrm{~b}$ & $27.79 c$ & $39.21 \mathrm{c}$ & $44.78 b$ & $50.88 \mathrm{~b}$ \\
\hline $\mathrm{S}_{45}$ & $8.63 f$ & $14.40 \mathrm{~d}$ & 19.31e & $29.85 e$ & $34.17 d$ & $37.04 d$ \\
\hline $\mathrm{S}_{60}$ & $14.97 b$ & $18.74 \mathrm{bc}$ & 25.98cd & 39.50c & $44.87 \mathrm{~b}$ & 49.36c \\
\hline $\mathrm{S}_{75}$ & I I.20e & $15.27 d$ & 20.77e & $34.15 d$ & $40.1 \mathrm{Ic}$ & $45.85 c$ \\
\hline $\mathrm{S}_{90}$ & $12.66 \mathrm{~cd}$ & $17.52 \mathrm{c}$ & 26.68cd & $35.91 d$ & 43.17b & $48.16 c$ \\
\hline$S_{105}$ & $12.82 \mathrm{~d}$ & $17.57 \mathrm{c}$ & $25.1 \mathrm{Id}$ & $38.44 \mathrm{c}$ & $43.35 b$ & $49.09 c$ \\
\hline CV(\%) & 4.13 & 4.54 & 3.97 & 2.95 & 2.74 & 3.53 \\
\hline F-test & $* *$ & $* *$ & $* *$ & $* *$ & $* *$ & $* *$ \\
\hline
\end{tabular}

Economic return

The highest (9146\%) marginal rate of return (MRR) with gross margin of Tk. 18184/ha were obtained from the sulphur level $\mathrm{S}_{60} \mathrm{~kg} / \mathrm{ha}$ (Table 4). From the economic point of view, it was found to be the most suitable fertilizer dose for cultivation of onion in soil under study and in its extrapolation area as well.

Table 4. Marginal analysis of cost undominated of of sulphur fertilizer on the yield of onion (Average of two years).

\begin{tabular}{l|c|c|l|l|l}
\hline $\begin{array}{c}\text { Cost undominated } \\
\text { treatment (kg/ha) }\end{array}$ & $\begin{array}{c}\text { TVC } \\
(\mathrm{Tk} / \mathrm{ha})\end{array}$ & $\begin{array}{c}\text { GM } \\
(\mathrm{Tk} / \mathrm{ha})\end{array}$ & $\begin{array}{c}\text { MVC } \\
(\mathrm{Tk} / \mathrm{ha})\end{array}$ & $\begin{array}{c}\text { MGM } \\
(\mathrm{Tk} / \mathrm{ha})\end{array}$ & $\begin{array}{c}\text { MRR } \\
(\%)\end{array}$ \\
\hline $5_{0}$ & 6896 & 983088 & - & - & - \\
$\mathrm{S}_{15}$ & 7312 & 110988 & 416 & 12684 & 3049 \\
$\mathrm{~S}_{30}$ & 7729 & 124271 & 414 & 13283 & 3185 \\
$\mathrm{~S}_{45}$ & 8146 & 144354 & 417 & 20083 & 4816 \\
$\mathrm{~S}_{60}$ & 8556 & 181844 & 410 & 37490 & 9146 \\
$\mathrm{~S}_{75}$ & 8976 & 198224 & 4420 & 3780 & 1753 \\
\hline
\end{tabular}

Note: Only fertilizers' cost has been considered

Gross return and variable cost were calculated considering the following rates for $2001-2002$ and 2002-2003. 
Cost of fertilizers: Urea $=$ Tk. 5.0/kg, TSP $=$ Tk. 12.0/kg, MP Tk. 8.0/kg, Gypsum Tk.5.0/kg, Cowdung $=$ Tk. 0.50/kg and price of onion $=$ Tk. 10.0/kg. TVC $=$ Total variable cost, GM Marginal variable cost, MGM = Marginal gross margin, MRR = Marginal rate of return

From the study, it may be concluded that application of $S_{75} \mathrm{~kg} / \mathrm{ha}$ can produce the maxmimum bulb yield of onion, but $S_{60} \mathrm{~kg} / \mathrm{ha}$ contributes to the highest economic return. On the other hand, sulphur application upto $45 \mathrm{~kg} / \mathrm{ha}$ increased the storage duration of onion bulbs and thereafter decreased slowly.

\section{References}

Adamicki, F. 2005. Effects of pre-harvest treatments and storage conditions on quality and shelf-life of onions. IV International Symposium on Edible Alliaceae ISHS Ac/a Horticulturae p.688

Ahmed, M. K. D. K. Aditya and. M.A. Siddique. 1988. Effect of nitrogen on sulphur application on growth and yield of onion. cv. Faridpur Bhatti. Bangladesh Honrt. 16(1): 36-41.

Ajay, K and 0. Singh, 1994. Role of sulphur in nutrient utilization and catalase activity in onion crop. Indian J. Agric. Res. 28: 15-19.

Anonymous. 1999. A study on the adaptability, yield and keeping quality of 16 exotic cultivars of onion in Bangladesh. Annual Report, Bang. Agril. Res. Ins. Joydebpur, Dhaka.

Bangladesh Bureau of Statistics. BBS. 2007. Statistical Year Book of Bangladesh. Statistick Division, Ministry of Planning, Government of the People's Republic of Bangladesh, Dhaka. p. 143.

Bell, A. A. 1981. Biochemical mechanism of disease resistance. Ann. Rev. Plant Physiol. 32: 2 1-81.

Food and Agricultural Organization (FAO). 1999. FAO quaterly bulletin of statistics. Food and Agricultural Organization of the United Nations, Rome, Italy. 12: 91.

Hussain, S. G. 1990. Sulphur in Bangladesh Agriculture. Sulphur in Agri. 14: 25-28.

Jaggi, R. C. and S.P. Dixit, 1999. Onion (A/hum cepa L.) responses to sulphur in representative vegetable growing soils of Kangra Vabiley of Himachal Pradesh. Indian I Agric. Sc. 69: 289-291.

Kumar, R., S. K. Singh and S. Smriti. 2002. Effect of sulphur and boron nutrition on growth, yield and quality of onion. Journal of Applied Biology 12(1/2): 40-46.

Lancaster, J., J. Farrant, J. Shaw, B. Bycroft, D. Brash. 2001. Does sulphur supply to the bulb affect storage of onions? International Symposium on Edible Alliaceae: Ac/ta Horticulturae Pp. 555. 
Palilov, N.A. 205. Storage of onion-the biological bases of onion storage. Symposium on Vegetable Storage: Acta Horticuhturae pp. 20.

Rafika, S.B., D.R. Mejda, B.K. Mohamed and C. Hatem. 2005. Onion storage ability and an inventory of onion post-harvest fungi in Tunisia. Tropical Science 46(2): 105-1 12.

Rahim. M., A. A. Husain and M.A. Siddique 1983. Production of bulb and storage ability of three cultivars of onion. Punjab Vegetable Grower 17/18: 13-20.

Srinivasan, R., V. Shanmugam, A. Kamalakannan and M. Surendran. 2002. Influence of fertilisers, host factors and storage conditions in relation to disease severity: a case study of black mould rot of onion. Ac/ta Phytopathologica et Entomologica Hungarica 37(13): 119-135. 